\title{
Decline in vitality of propagules of Phytophthora pluvialis and Phytophthora kernoviae and their inability to contaminate or colonise bark and sapwood in Pinus radiata export log simulation studies
}

Ian A Hood ${ }^{1}$, Nari M Williams ${ }^{1 *}$, Margaret A Dick', Natalija Arhipova ${ }^{2}$, Mark O Kimberley ${ }^{1}$, Peter M Scott ${ }^{1}$ and Judy F Gardner ${ }^{1}$

\begin{abstract}
Background: Phytophthora pluvialis Reeser, W.L. Sutton \& E.M. Hansen is the cause of a newly described disease, red needle cast, in certain stands of Pinus radiata D. Don in New Zealand that experience periodic foliage browning, while Phytophthora kernoviae Brasier, Beales \& Kirk is also infrequently isolated from symptomatic needles. Methods: Studies were undertaken to test the possibility that these species may be transported on pine logs either as superficial contaminants or as colonists of bark or wood.

Results: Pine-needle baiting found no evidence of Phytophthora species in bark samples or aqueous bark washes from stems of 603 symptomatic trees in 17 affected stands implying that survival after natural deposition of sporangia or zoospores is low or absent. The persistence of zoospores or oospores was evaluated at intervals after applying them at artificially high surface densities to the bark on log segments and incubating at five temperatures between $15^{\circ} \mathrm{C}$ and $35^{\circ} \mathrm{C}$ in the laboratory. The ability to re-isolate Phytophthora kernoviae decreased with time and increasing temperature, but this species was still obtained at low frequencies after 4 weeks at $15^{\circ} \mathrm{C}$ and $20^{\circ} \mathrm{C}$ following treatment with oospores of Phytophthora kernoviae. Phytophthora pluvialis could not be isolated under any conditions of time or temperature tested. Percentage vitality of oospores of both species as determined using tetrazolium bromide vital staining also decreased with time, although some oospores of both species remained alive after 4 weeks at all temperatures tested. In a further study to test potential log colonisation, Phytophthora spp. were not isolated from bark or xylem at or near points where zoospores, oospores or mycelium of either species were applied to the bark or sapwood of pine segments and incubated for 6 weeks under ambient or humid conditions at $17^{\circ} \mathrm{C}$.

Conclusion: The results of these studies suggest that occurrence of Phytophthora kernoviae or Phytophthora pluvialis on export logs from affected stands is negligible. In addition, although some remained alive, the substantial decline in vitality among artificially applied oospores implies that the survival of any few that may be naturally present on logs is likely to be slight. Based on the evidence from this work there appears to be little risk of transporting these Phytophthora species on New Zealand radiata pine logs.
\end{abstract}

Keywords: Pinus radiata; Phytophthora; Needle blight; Log transport; Export logs; Disease risk

\footnotetext{
*Correspondence: nari.williams@scionresearch.com

'Scion (New Zealand Forest Research Institute), Private Bag 3020, Rotorua 3046, New Zealand

Full list of author information is available at the end of the article
} 


\section{Background}

Unexplained browning of foliage has been an intermittent feature of some Pinus radiata D. Don stands in parts of New Zealand since at least 2008 (Dick et al. 2014). This discoloration has appeared only in some years mainly in plantations in the northern, eastern, and central parts of the North Island (i.e. Northland, Auckland, Coromandel, Bay of Plenty, Taupo, Gisborne) and in the northern South Island (i.e. Nelson and Marlborough regions) (Crosby et al. 1988). The disorder is now known as red needle cast from the colour that develops over the crowns of affected trees. Symptoms first appear between March and August (autumn or winter), depending on the region. Short, pale green, discrete lesions (in which small, black, often band-like, resinous marks are usually present) develop on green needles, which then turn brown before eventually being shed. Crowns may remain brown until November (late spring) when diseased foliage is replaced by the new season's growth.

Freshly affected needle tissues regularly yield isolates of either Phytophthora pluvialis Reeser, W.L. Sutton \& E.M. Hansen or Phytophthora kernoviae Brasier, Beales \& Kirk, the latter being obtained at much lower frequencies (Dick et al. 2014). Phytophthora pluvialis has only recently been described from mixed forest in Oregon, the only other region where it is known to occur (Reeser et al. 2013). Concurrent pathogenicity studies have indicated that $P$. pluvialis is the causal agent of red needle cast (Dick et al. 2014), with the role of Phytophthora kernoviae still to be clarified. Phytophthora kernoviae has been present in New Zealand for at least 60 years but has only rarely been associated with disease in this country (Ramsfield et al. 2009; Dick et al. 2014). By contrast, Phytophthora kernoviae is pathogenic on a number of forest, heathland and ornamental angiosperm hosts in the United Kingdom (Brasier et al. 2005; Beales et al. 2009). Another species which infects Pinus radiata foliage in Chile, Phytophthora pinifolia Dúran, Gryzenhout \& M. J. Wingfield (Dúran et al. 2008), has not been isolated here, and there is no evidence that it is present in New Zealand.

The occurrence of Phytophthora pluvialis and Phytophthora kernoviae might present a potential biosecurity risk if these oomycete species can be carried on logs exported to other countries. Studies were therefore undertaken to find out whether their propagules are able to colonise bark of Pinus radiata logs or survive on the bark surface long enough to be carried overseas. This work was conducted by examining three aspects: 1 . natural occurrence of propagules on the bark surface; 2 . survival of propagules artificially applied to the bark surface; and 3. colonisation of bark and sapwood by Phytophthora propagules.

\section{Methods}

Natural occurrence of Phytophthora propagules on the bark surface

Sites

The bark on Pinus radiata trees affected by red needle cast was examined for evidence of viable propagules of Phytophthora pluvialis and Phytophthora kernoviae deposited naturally on the prospective log surface. The trees investigated were located at 17 sites in an area 50$70 \mathrm{~km}$ wide that spanned two regions (Bay of Plenty and Taupo) in the central North Island of New Zealand. Altogether 603, 14- to 25-year-old trees were selected, matching the number at each site to the level of disease and the size of the stand. All showed moderate to high levels of browning in the lower third of the canopy and characteristic lesions were present on a selection of needles collected from 429 of the trees. Confirmation that they were affected by red needle cast was furnished in the laboratory by the isolation of Phytophthora spp. from $78 \%$ of the needle samples after surface sterilising in $70 \%$ ethanol for 30 seconds, rinsing in two washes of sterile deionised water for 30 seconds, plating onto $\mathrm{P}_{10} \mathrm{ARP}$ agar selective medium (Jeffers and Martin 1986, but with pentachloronitrobenzene reduced to $25 \mathrm{mg} \mathrm{L}^{-1}$ ), and incubating at $17^{\circ} \mathrm{C}$.

\section{Sampling}

Sampling was undertaken in August-September 2012 when disease expression was at a maximum and the occurrence of propagules of these Phytophthora species was potentially the most abundant (Dick et al. 2014). Four bark samples measuring approximately 5 x $10 \mathrm{~cm}$ were taken at breast height from around each tree. On the same tree, $1 \mathrm{~L}$ of deionised water was poured in a gentle stream from a broad mouthed flask over a $1 \mathrm{~m}$ length of bark between 0.5 and $1.5 \mathrm{~m}$ above ground level, targeting crevices and natural water channels on the surface. Approximately 400-500 mL of runoff water was collected in a polythene bag from each tree and transferred to a collection bottle. All samples were taken to the laboratory within 6 hours for testing.

\section{Sample baiting}

In the laboratory, samples were tested for the presence of Phytophthora spp. by baiting in water. Bark pieces were placed into shallow trays, flooded with deionised water and baited for 7 days with freshly-collected Pinus radiata needles and Rhododendron ponticum L. leaves. A total of $300 \mathrm{~mL}$ from each bark wash sample was baited in the same way for 5 days. Foliage baits from both sets were blotted dry, plated onto $\mathrm{P}_{10} \mathrm{ARP}$ medium, incubated at $17^{\circ} \mathrm{C}$ and observed for 21 days for the production of Phytophthora spp. colonies. 


\section{Survival of artificially applied Phytophthora propagules on the bark surface}

The survival of propagules of Phytophthora spp. applied artificially to the bark surface of segments of Pinus radiata was examined by means of three studies. Because the studies were conducted in essentially the same way they are described together, noting differences between them where applicable.

\section{Stem segments}

The studies were undertaken using stem segments with the bark retained on one longitudinal face cut from billets taken from Pinus radiata trees growing in the Bay of Plenty and Taupo regions. Details of the age and number of trees as well as the number and dimensions of the segments used in each study are shown in Table 1. Segments were cut within one day of felling (or in 3 months for one tree in Study 3, to test the effect of stem age; Table 1). After cutting they were held in sealed polythene bags at $4^{\circ} \mathrm{C}$ for up to 1 month until 1 day prior to each treatment. Before treatment, bark surfaces were first brushed to remove loose dirt, sawdust and most lichen growth.

\section{Isolates}

The isolates used in these studies are listed in Tables 1 and 2 . They were obtained by plating symptomatic needle tissue from diseased trees onto $\mathrm{P}_{10} \mathrm{ARP}$ agar and after isolation were maintained on blocks of carrot agar (Erwin and Ribeiro 1996) under sterile deionised water at $4^{\circ} \mathrm{C}$.

\section{Production of propagule suspensions}

Oospore suspensions were produced for each species, as follows. Isolates of Phytophthora kernoviae were cultured by placing blocks cut from carrot agar cultures into Petri dishes containing $20 \mathrm{~mL}$ sterile clarified V8 juice broth (Campbell's Soups Australia ${ }^{\mathrm{Tm}}$ ) amended with $\mathrm{CaCO}_{3}$ (Erwin and Ribeiro 1996). These were sealed with Parafilm ${ }^{\mathrm{TM}}$ and incubated at $20^{\circ} \mathrm{C}$ for $2-8$ weeks. Isolates of Phytophthora pluvialis were grown either on carrot agar or in clarified carrot broth (Erwin and Ribeiro 1996) at $17^{\circ} \mathrm{C}$ or $20^{\circ} \mathrm{C}$ for $6-8$ weeks. Oospore suspensions were prepared by removing and suspending mycelia in ca. $20 \mathrm{~mL}$ non-sterile deionised water in a small beaker, and sonicating to separate oospores from the mycelium. Within each study the different isolates of each species were combined before sonication (Table 1). For one oospore treatment of each species in Study 1, suspensions were heated to $35^{\circ} \mathrm{C}$ for at least $2 \mathrm{hr}(2 \mathrm{hr}$, Phytophthora pluvialis; $15 \mathrm{hr}$, Phytophthora kernoviae; Treatments C and D in Table 1), with the intention of killing the more vulnerable living mycelial fragments without harming the oospores (Theron et al. 1982).

Zoospore suspensions were prepared from sporangia produced in culture. Those of Phytophthora kernoviae were obtained by immersing sections of agar taken from the leading edge of 3-day-old carrot agar cultures in sterile pond water in sealed Petri dishes, which were incubated for $2-4$ days at $20^{\circ} \mathrm{C}$. Phytophthora pluvialis sporangia were induced by first immersing sections of agar taken from the leading edge of 3-day-old cultures growing on carrot agar in carrot broth for 3 days and incubating at $17^{\circ} \mathrm{C}$. Mycelial mats were then rinsed three

Table 1 Details of studies to determine the survival of propagules of Phytophthora species applied to the bark surface of segments cut from Pinus radiata stems harvested in the Bay of Plenty and Taupo regions

\begin{tabular}{|c|c|c|c|c|c|}
\hline \multirow[t]{2}{*}{ Study } & \multirow[t]{2}{*}{ Treatment $^{1}$} & \multirow[t]{2}{*}{ Application method } & \multirow{2}{*}{$\begin{array}{l}\text { No. replicates } \\
\text { (segments) }\end{array}$} & \multicolumn{2}{|c|}{ Segments } \\
\hline & & & & Dimensions (cm) & Age of parent tree $(y r)$ \\
\hline \multirow[t]{5}{*}{1} & A.P. kernoviae oospores & Direct & $3(75)$ & $30 \times 9 \times 9$ & 36 \\
\hline & B. P. kernoviae mixed sporangia and zoospores & & & & \\
\hline & C. P. pluvialis oospores (heated) ${ }^{2}$ & & & & \\
\hline & D. P. kernoviae oospores (heated) ${ }^{2}$ & & & & \\
\hline & E. Deionised water (control) & & & & \\
\hline \multirow[t]{2}{*}{2} & A. P. kernoviae oospores & On nylon mesh filter & $2(20)$ & $30 \times 9 \times 9$ & 32 \\
\hline & F. P. pluvialis oospores & & & & \\
\hline \multirow[t]{2}{*}{3} & B. P. kernoviae mixed sporangia and zoospores & Direct & $3(60)^{3}$ & $10 \times 9 \times 9$ & 15 \\
\hline & G. P. pluvialis mixed sporangia and zoospores & & & & \\
\hline
\end{tabular}

${ }^{1}$ Phytophthora isolates: refer Table 2 for details:

Study 1: P. kernoviae: 3610, 3614; P. pluvialis: 3026, 3608, 3613, 3619, 3626, 11135-1.

Study 2: P. kernoviae: 3610, 3614, 3636; P. pluvialis: 3619, 3626.

Study 3: P. kernoviae: 3604,3614 ; P. pluvialis: $3613,3619$.

Isolates of each species were combined within each study.

${ }^{2}$ Heated to kill mycelial fragments prior to application.

${ }^{3}$ Cut the same day from two trees in one stand, felled immediately or 3 months earlier in late autumn, treated experimentally as separate blocks each with 30

segments (one tree felled immediately for each of Studies 1 and 2). 
Table 2 Isolates of Phytophthora species used in these studies

\begin{tabular}{|c|c|c|c|c|c|}
\hline Species (Phytophthora) & Isolate (NZFS ${ }^{1}$ ) & Host (Pinus) & Location & Region $^{2}$ & Date \\
\hline \multirow[t]{4}{*}{ P. kernoviae } & 3604 & P. radiata & Mata Forest & Gisborne & May 2011 \\
\hline & 3610 & P. radiata & Mahurangi Forest & Auckland & Jun 2011 \\
\hline & 3614 & P. radiata & Turitea & Wellington & Jun 2011 \\
\hline & 3636 & P. radiata & Hikumutu Forest & Taupo & Aug 2011 \\
\hline \multirow[t]{6}{*}{ P. pluvialis } & 3026 & P. radiata & Kaingaroa Forest & Taupo & Aug 2008 \\
\hline & 3608 & P. radiata & Glenbervie Forest & Northland & Jun 2011 \\
\hline & 3613 & P. radiata & Turangakuma Forest & Taupo & May 2011 \\
\hline & 3619 & P. radiata & Moutere Sth Forest & Nelson & Aug 2011 \\
\hline & 3626 & P. strobus L. & Highlands Forest & Bay of Plenty & Aug 2011 \\
\hline & 11135-1 & P. radiata & Waipu Forest & Northland & Jun 2011 \\
\hline
\end{tabular}

${ }^{1}$ New Zealand Forest Research Institute Culture Collection, Rotorua, New Zealand (11135-1 not held in NZFS).

${ }^{2}$ Crosby et al. (1988).

times with sterile distilled water, flooded with sterile pond water and incubated for a further $3-4$ days at $17^{\circ}$ C. Plates of both species were placed at $4^{\circ} \mathrm{C}$ for $1 \mathrm{hr}$ and returned to $20^{\circ} \mathrm{C}$, in some instances positioned on a light box (Zentmyer and Ribeiro 1977), to induce zoospore release. Zoospore suspensions of different isolates of the same species were combined within each study (Table 1).

Concentrations were determined by counting sets of 10 samples per suspension under the microscope using a haemocytometer. The zoospore samples were first vortexed to render the zoospores immobile before counting (Erwin and Ribeiro 1996). Suspensions of all propagules were then diluted to final application volumes with deionised water. Suspensions were applied within a few hours of preparation.

\section{Application to bark surface}

Within each study the different treatments were applied on the same day with the exception of Study 1 in which they were applied separately under equivalent conditions over a 2-week period due to the unavoidable variation in maturation and rates of production of propagules in culture. Immediately before treatment, bark surfaces were lightly moistened with a mist of deionised water, but were not surface sterilised. In Studies 1 and 3 the treatment suspensions were applied evenly by hand as a fine spray across the whole bark face. Volumes applied per segment ranged between 5 and $25 \mathrm{~mL}$ for different treatments. Propagule densities on the bark surfaces, calculated from the haemocytometer counts and volumes applied, were estimated at between 300 and $600 \mathrm{~cm}^{-2}$ for oospores, $200 \mathrm{~cm}^{-2}$ for Phytophthora pluvialis zoospores, and 1,800 or $200 \mathrm{~cm}^{-2}$ (studies 1, 3, respectively) for Phytophthora kernoviae zoospores.

In Study 2, oospores were applied embedded in nylon net filter discs (diameter $47 \mathrm{~mm}, 20 \mu \mathrm{m}$ mesh, Millipore $^{\mathrm{Ts}}$; Table 1; Etxeberria et al. 2011). Aliquots (5 mL per disc) of each suspension were filtered through each mesh under suction. Three discs of one species were stapled to each segment. On one segment of each treatment discs were placed with the upper surface (as positioned during vacuum filtration) upwards and on a second segment the disc was fastened inverted. Numbers of oospores embedded on each nylon disc filter were estimated as previously at between 1,000 and $4,000 \mathrm{~cm}^{-2}$.

\section{Exposure to different temperatures}

After treatment, segments were placed bark uppermost in plastic boxes with loosely fitting lids, separated by thin cards, with each box containing all treatments. In Study 1 segments were positioned in two layers separated vertically by cylindrical solid plastic spacer rods. All boxes and segments were then positioned in chambers, with 2 or 3 replicates per chamber (Table 1 ), and each chamber held at one of five temperatures: $15^{\circ} \mathrm{C}, 20^{\circ} \mathrm{C}, 25^{\circ} \mathrm{C}$, $30^{\circ} \mathrm{C}, 35^{\circ} \mathrm{C}$, with relative humidity set at $80 \%$. Lighting was provided by cool white fluorescent tubes for intervals that varied between $12 \mathrm{hr}$ and $16 \mathrm{hr}$ in a 24-hr period due to an unintended programming error. Segments were incubated for periods up to 6 weeks in the different studies.

\section{Assessment of vitality and viability}

Propagule vitality (percentage living) or viability (percentage able to germinate or propagate) was assessed by sampling at intervals during each study using four methods: direct isolation (Studies 1 and 3, only), vital staining, germination, and plating of extracted oospores onto a Phytophthora-selective medium. Only isolation was used in Study 3. In Study 1, sampling for vital staining, germination and oospore plating was undertaken between 3 and 3.5 weeks and between 4 and 4.5 weeks after application, for different treatments and replicates. 
Direct isolation To isolate, cores extracted antiseptically from across the bark surface of each segment during each sampling interval using a Number 3 cork-borer (core diameter, $6.5 \mathrm{~mm}$; 10 cores per segment per interval, 3750 cores, total), were plated, outer face down, onto the surface of $\mathrm{P}_{10} \mathrm{ARP}$ agar. Plates were incubated at $20^{\circ} \mathrm{C}$ and monitored for a minimum of 3 weeks for emerging cultures. Suspected Phytophthora spp. isolates were identified morphologically from hyphae and by transferring subcultures on blocks of carrot agar to pond water in order to encourage the production of sporangia as described earlier.

Vital staining Vital staining was undertaken with tetrazolium bromide (Sutherland and Cohen 1983). On each occasion oospores were washed from bark samples of segments as follows. A piece of outer bark ca. $2 \mathrm{~cm} \times$ $1 \mathrm{~cm}$ was cut from each segment and placed in a centrifuge tube with ca. $5 \mathrm{~mL}$ deionised water. This was vortexed twice for periods of $30 \mathrm{sec}$ separated by an interval at rest of $30 \mathrm{~min}$. After removing the bark with sterile forceps the tube was centrifuged for $5 \mathrm{~min}$ and the supernatant pipetted off, leaving ca. $0.7 \mathrm{~mL}$ of residual fluid. After another very brief vortexing, ca. $0.2 \mathrm{~mL}$ was removed for the evaluations of germination and growth on selective medium (see below). An amount of $0.5 \mathrm{~mL}$ of $0.1 \%$ tetrazolium bromide solution (thiazolyl blue tetrazolium bromide) was mixed with the remaining $0.5 \mathrm{~mL}$ fluid in the tube, and this was incubated in a water bath at $35^{\circ} \mathrm{C}$ for $48 \mathrm{hr}$, after which the percentage of oospores clearly staining pink or purple was counted cumulatively under a microscope from sets of samples taken from each tube (counts, per replicate, of up to 50 oospores, Study 1; and up to 100, Phytophthora pluvialis, or 1000, Phytophthora kernoviae, Study 2). At each evaluation interval after segment treatment, the validity of the tetrazolium staining procedure was tested using freshly prepared oospore suspensions.

At each sampling interval in Study 2, one randomly selected nylon mesh disc was removed from each segment and cut into two halves. The oospores on one portion were stained by covering with a 1:1 deionised water: $0.1 \%$ tetrazolium bromide solution mixture and incubating as described above. Percentage oospore vitality was determined by counting directly from the mesh positioned arbitrarily under a microscope.

Germination Percentage oospore germination was determined by placing a $0.1 \mathrm{~mL}$ sub-aliquot of each bark washing sample in the well of a cavity microscope slide. These were held at $20^{\circ} \mathrm{C}$ in a damp chamber. A portion from each freshly prepared control oospore suspension was also placed in a cavity slide. In study 2, percentage germination was determined in the same way after extracting oospores from the other half of the nylon mesh using the same procedure as for bark segments. Repeat counts of percentage germination were made under a microscope 1 and 2 weeks (Study 1), or at approximately 2-week intervals for up to 6.5 weeks (Study 2), after placing in slide cavities.

Growth on a selective medium Survival was also determined by testing growth from oospore suspensions on the Phytophthora-selective medium. The remaining $0.1 \mathrm{~mL}$ portion of each bark washing, part of the suspension of oospores extracted from the second half of the nylon mesh, and the balance of the freshly prepared controls, was pipetted onto $\mathrm{P}_{10} \mathrm{ARP}$ agar. Plates were incubated at $20^{\circ} \mathrm{C}$ and monitored for up to 6 weeks for emerging cultures. Suspected Phytophthora isolates were identified morphologically as before.

\section{Statistical analysis}

Statistical analyses were performed on percentage of cores yielding isolates and percentage of oospores staining positive. Both dependent variables were transformed prior to analysis using the angular (or arcsine) transformation, and all means reported in this paper are back-transformed means (unless otherwise stated). A series of multi-factor ANOVAs (analyses of variance) were fitted using the SAS Version 9.2 PROC MIXED procedure to test the effects of temperature, treatment, and time since application as appropriate for each data set. All ANOVAs were of split-plot form (treatment within box within temperature, with box fitted as a random effect in the model), and with time since application fitted as a repeated measures term with unstructured covariance.

\section{Colonisation of bark and sapwood}

The bark and sapwood of Pinus radiata log segments were inoculated with different propagules to see if logs could be colonised and so potentially act as carriers of Phytophthora species. The experiment was established using a randomised split-plot design with independent variables being the application of propagules directly to the bark surface or to sapwood; and ambient or moist conditions of incubation. Each isolate was replicated with five independent blocks.

\section{Stem segments}

Eighty fresh log segments measuring $20 \times 20 \times 5 \mathrm{~cm}$ with bark retained on one surface were cut from two trees in a 15-year-old stand in Rotorua. Segments were assigned to inoculation of either bark or sapwood. 


\section{Inoculum}

Inoculations were undertaken with oospores, zoospores or mycelium of two isolates of Phytophthora pluvialis (NZFS 3613, 3626) and two of Phytophthora kernoviae (NZ3604, 3614) (Table 2). Oospore and zoospore suspensions were prepared as described above and all standardised to a concentration of 4,000 spores $\mathrm{mL}^{-1}$. Mycelium inoculum was prepared by growing Phytophthora pluvialis and Phytophthora kernoviae for five days on cellophane over carrot agar.

\section{Treatment}

The three propagule treatments of one isolate plus a sterile deionised water only control were applied per segment. Four inoculation points were marked at evenly spaced distances $(\mathrm{ca} .10 \mathrm{~cm}$ ) in a square pattern with fine mounting pins. For bark inoculations inoculum was applied directly whereas sapwood inoculations were performed after removing the bark down to the cambium with a number- 3 cork-borer. A volume of $50 \mu \mathrm{L}$ was then applied to each respective inoculation point. For mycelium, the cellophane was peeled and cut into $5 \mathrm{~mm}$ squares. One square was pinned at each inoculation point, mycelium side down to ensure direct contact between it and the bark surface.

Following treatment, and after a brief interval to allow inoculum suspensions to dry, the segments were stored in a constant temperature room at $17^{\circ} \mathrm{C}$ under moist or ambient conditions for 6 weeks. One set of segments was placed individually in closely fitting sealed polythene bags to maintain high humidity, while the remainder were stored un-bagged.

\section{Evaluation}

At harvest, samples of bark (if present) and sapwood were taken from the inoculation point and at a distance $5 \mathrm{~mm}$ from the inoculation point using a number-3 cork-borer. The cores with bark were aseptically dissected to separate bark from sapwood, and all sections were plated directly, inoculation side down, onto $\mathrm{P}_{10} \mathrm{ARP}$ agar. Cultures were monitored for 21 days for the emergence of Phytophthora hyphae.

\section{Results}

Natural occurrence of Phytophthora propagules on the bark surface

No Phytophthora isolates were recovered from either bark washings or baited bark from any of the 603 trees sampled.

\section{Survival of artificially applied propagules on the bark surface}

\section{Direct isolation}

Most isolation attempts from segment bark in Study 1 yielded cultures of different fungi at frequencies varying between $59 \%$ and $80 \%$ over all periods after treatment. No Phytophthora species were obtained from segments treated with Phytophthora kernoviae sporangia and zoospores (Treatment B, unheated), Phytophthora pluvialis oospores (Treatment C, heated), or the uninoculated control (Table 1). However, Phytophthora kernoviae was isolated from segments treated with oospores of Phytophthora kernoviae (Treatments A and D, unheated and heated, respectively) and only data from these two treatments were analysed statistically. Results are shown in Figures 1 and 2 .

A separate ANOVA of the Day-1 data confirmed there was no significant difference in percentage isolation of Phytophthora kernoviae between temperatures at the start of the trial $\left(\mathrm{F}_{4,8}=0.45, p=0.77\right)$. However, isolation decreased significantly with time, with the decrease occurring more rapidly at higher temperatures. No successful isolations after Day 1 were recorded at temperatures greater than $20^{\circ} \mathrm{C}$. A repeated measures ANOVA comparing both treatments over time for the $15^{\circ} \mathrm{C}$ and $20^{\circ} \mathrm{C}$ temperatures only, showed a significant decline over time $\left(\mathrm{F}_{4,44}=19.48, p<0.0001\right.$; Figures 1 and $\left.2 \mathrm{~A}\right)$, with a mean isolation yield of $21.4 \% 1$ day after application, $16.6 \%$ at Day $7,8.8 \%$ at Day 14, and near zero isolations at Days 21 and 28. There was no difference between isolation

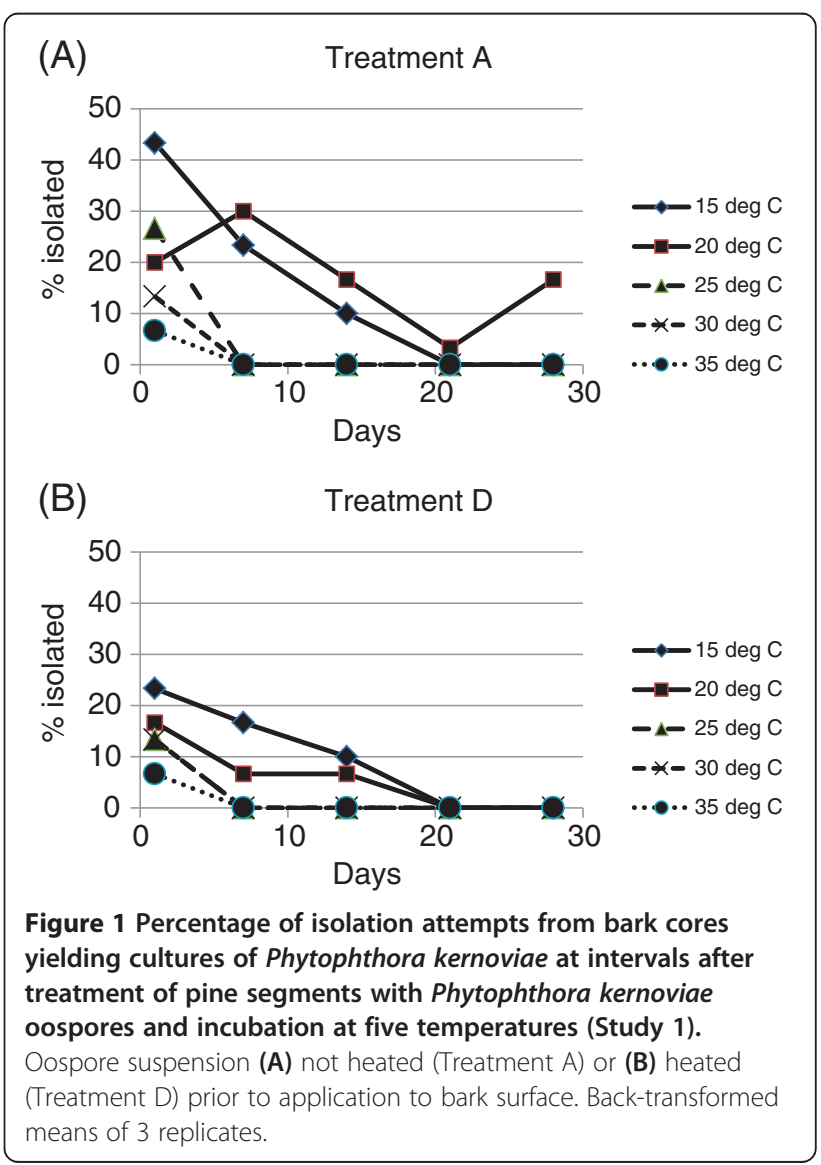




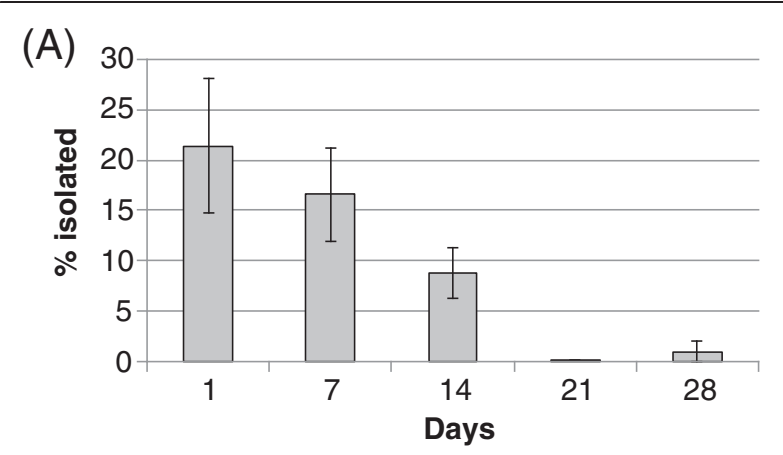

(B) 30

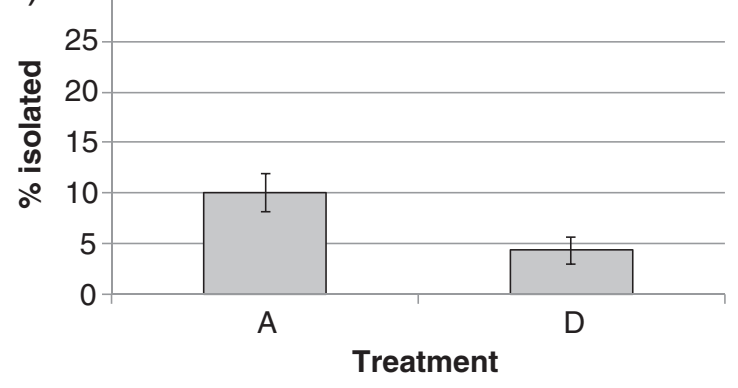

Figure 2 Percentage of isolation attempts yielding cultures of Phytophthora kernoviae after application of oospores to the bark surface for heat treated and untreated oospore suspensions in Study 1 (back transformed means with standard errors). (A) By time after application (days) and (B) by treatment: (A, not heated and $\mathrm{D}$, heated prior to application), both for $15^{\circ} \mathrm{C}$ and $20^{\circ} \mathrm{C}$

yields at $15^{\circ} \mathrm{C}$ and $20^{\circ} \mathrm{C}$ averaged across treatments and time intervals $\left(\mathrm{F}_{1,2}=0.18, p=0.71\right)$.

Percentage isolation of Phytophthora kernoviae was significantly less when oospores were heated before application (Treatment D, 4.4\%) than when they were not (Treatment A, $10.1 \%$; averaged across $15^{\circ} \mathrm{C}$ and $20^{\circ} \mathrm{C}$ and all time intervals; $\mathrm{F}_{1,5}=8.31, p=0.035$; Figures 1 and $2 \mathrm{~B}$ ). This was true even at Day 1 (means for Treatments D, A, respectively, $11.4 \%, 26.3 \% ; \mathrm{F}_{1,14}=11.58, \mathrm{p}=$ 0.0043).

As in Study 1, isolation attempts after application of zoospores of both species in Study 3 did not yield cultures of either Phytophthora kernoviae or Phytophthora pluvialis following incubation at any of the temperatures tested for periods from 24-96 hours. Viability of applied zoospore suspensions was confirmed by re-isolation onto the selective medium at time of treatment.

\section{Vital staining}

Counts of percentages of oospores of Phytophthora kernoviae and Phytophthora pluvialis staining positive (pink or purple, interpreted as still living) with tetrazolium bromide also revealed a strong reduction in vitality with time during Study 1, when compared with freshly prepared controls (Figure 3). Tests were performed

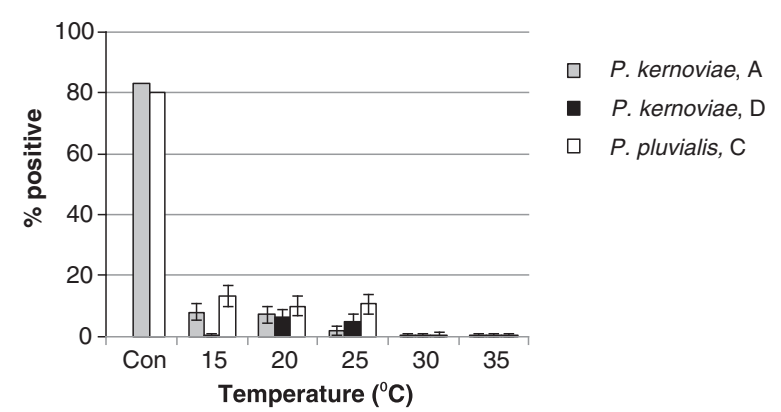

Figure 3 Percentage of oospores of the two Phytophthora species showing a positive reaction to tetrazolium bromide vital stain after $3-4.5 \mathrm{wk}$ incubation at five temperatures in Study 1 (back transformed means with standard errors). Phytophthora kernoviae (treatments A and D, not heated and heated prior to application to segments respectively); Phytophthora pluvialis (treatment C, heated prior to application to segments); $C$ on $=$ fresh unheated controls.

3 - 3.5 weeks after treatment, and again $4-4.5$ weeks after treatment. For reasons that are not clear, percentage of positive staining oospores was significantly lower for the first time period than for the second, later time period (mean $1.3 \%$ for weeks $3-3.5$ and $5.1 \%$ for weeks $4-4.5$ ). Means by temperature and treatment for the two periods combined are shown in Figure 3. Oospore vitality was again strongly influenced by the incubation temperature $\left(\mathrm{F}_{4,8}=10.15, p=0.0032\right)$. The percentage of oospores staining positive after $3-4.5$ weeks' exposure to temperatures of $15^{\circ} \mathrm{C}, 20^{\circ} \mathrm{C}$ and $25^{\circ} \mathrm{C}(5.6 \%, 7.8 \%$ and $5.3 \%$ respectively) was greater than those exposed to $30^{\circ} \mathrm{C}$ and $35^{\circ} \mathrm{C}(0.2 \%$ and $0.3 \%$ respectively). There was also a significant treatment effect $\left(\mathrm{F}_{2,28}=5.15, p=0.013\right)$. The percentage of positively stained oospores was greater for Phytophthora pluvialis (Treatment C, mean $=5.3 \%$ ) than for Phytophthora kernoviae (Treatments A and D, not heated and heated, means $=2.5 \%$ and $1.6 \%$, respectively). There were no significant interactions between incubation temperature, treatment and sampling interval.

In Study 2 percentages of positive staining oospores on the nylon meshes also decreased with time when compared with those for the freshly prepared control suspensions (Figure 4; positive staining controls ranged 96-99\% for Phytophthora kernoviae and 64-73\% for Phytophthora pluvialis over the full study period). These percentages were somewhat greater than for those directly applied to the bark surface in Study 1 (Figure 3). Analysis of data from Study 2 showed a significant interaction between Phytophthora species and sample time $\left(\mathrm{F}_{2,20}=27.18, p<0.0001 ;\right.$ Figure 4$)$. The mean percentage of positive staining oospores was less after 21 and 33 days $\left(26.7 \%, 25.9 \%\right.$, respectively) than after 1 day $\left(63.7 \%\right.$; $F_{2,20}$ $=97.22, p<0.0001)$. After 1 day oospore vitality was greater for Phytophthora kernoviae (82.4\%) than for 


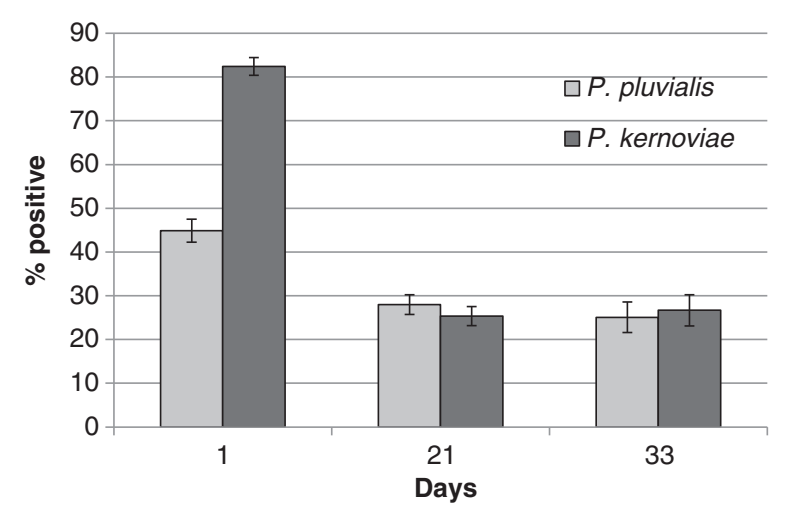

Figure 4 Percentage oospores of Phytophthora kernoviae and Phytophthora pluvialis showing a positive reaction to tetrazolium bromide vital stain for each sample time in Study 2 (back transformed means with standard errors).

Phytophthora pluvialis (44.9\%;), but there was no difference between species thereafter $(p>0.05)$. In this study, temperature did not influence oospore vitality $\left(\mathrm{F}_{4,4}=\right.$ $4.08, p=0.10)$. There was also no significant difference between filter placed upwards or inverted (means $39.7 \%$, 37.5\%, respectively; $p>0.05$ ).

\section{Germination}

Oospores of Phytophthora kernoviae germinated in cavity slides to produce germ tubes and sporangia, the latter often releasing motile zoospores. Percentages of germinated oospores in Study 1 are shown in Table 3. Values in freshly prepared control suspensions were $49 \%$ for the $3-3.5$ week sampling interval and $5 \%$ for the $4-4.5$ week interval (evaluated after 2 weeks in the cavity slide; the
$4-4.5$ week value increased to $48 \%$ after 6.5 weeks in the cavity slide). By contrast, values for oospores from bark washings (Treatments A and D) were all $0 \%$ for both time intervals (weeks $3-3.5$ and $4-4.5$ ). No oospores of Phytophthora pluvialis germinated, whether from bark washes or, even after 6.5 weeks, in the control suspension.

In Study 2, percentage germination of Phytophthora kernoviae oospores from the nylon mesh circles sampled 1 day after treatment ranged from 17 to $38 \%$ after 6 weeks in water in cavity slides (Table 4). At this sampling time there was no significant difference between percentage germination at different temperatures $\left(\mathrm{F}_{4,5}=\right.$ 1.97, $p=0.24)$. However, there was no germination of oospores from at least 3 weeks after treatment (Table 4). Mean germination of freshly prepared control oospore suspensions of Phytophthora kernoviae at different sampling times ranged from 45 to $65 \%$ after 6 weeks in cavity slides (Table 4). Where germination of Phytophthora kernoviae occurred (controls and Day 1 bark applications) germination percentages increased steadily during repeat counts made at 2-, 4-, and 6-week intervals. No oospores of Phytophthora pluvialis from control suspensions or nylon discs germinated at any time after application to segments (Table 4).

\section{Growth on a selective medium}

In Studies 1 and 2, freshly prepared control suspensions of oospores of both Phytophthora species all produced colonies of the respective species from drops placed onto the Phytophthora-selective medium. By contrast, most bark washing and nylon mesh oospore suspensions did not produce Phytophthora cultures on this medium. However, a colony of Phytophthora kernoviae grew from

Table 3 Percentage oospore germination of Phytophthora kernoviae after 2 weeks in the cavity slides in Study 1 (untransformed means for 3 replicates, $\mathbf{n}$ being the total No. of oospores)

\begin{tabular}{|c|c|c|c|c|c|}
\hline \multirow[t]{3}{*}{ Treatment } & \multirow{3}{*}{$\begin{array}{l}\text { Temperature } \\
\left({ }^{\circ} \mathrm{C}\right)\end{array}$} & \multicolumn{4}{|c|}{ Time after application to bark } \\
\hline & & \multicolumn{2}{|c|}{$3-3.5 w k$} & \multicolumn{2}{|c|}{$4-4.5$ wk } \\
\hline & & Mean\% & $\mathbf{n}$ & Mean\% & n \\
\hline Fresh control $^{1}$ & - & 49 & 151 & $5^{2}$ & 300 \\
\hline \multirow[t]{5}{*}{ Bark applied (not heated; Treatment A) } & 15 & 0 & 43 & 0 & 2 \\
\hline & 20 & 0 & 3 & 0 & 3 \\
\hline & 25 & 0 & 173 & 0 & 1 \\
\hline & 30 & 0 & 3 & 0 & 4 \\
\hline & 35 & 0 & 172 & 0 & 2 \\
\hline \multirow[t]{5}{*}{ Bark applied (heated; Treatment D) } & 15 & 0 & 35 & 0 & 2 \\
\hline & 20 & 0 & 8 & - & 0 \\
\hline & 25 & 0 & 118 & 0 & 5 \\
\hline & 30 & 0 & 7 & 0 & 5 \\
\hline & 35 & 0 & 243 & 0 & 9 \\
\hline
\end{tabular}

${ }^{1}$ Control suspensions prepared fresh at each sampling time $(2,1$ replicates, respectively).

${ }^{2} 48 \%$ after $6.5 \mathrm{wks}$ in the cavity slides. 
Table 4 Percentage Phytophthora spp. oospore germination after 6 weeks in the cavity slides in Study 2 (untransformed means for $\mathbf{2}$ replicates, $\mathbf{n}$ being the total number of oospores)

\begin{tabular}{|c|c|c|c|c|c|c|c|c|}
\hline \multirow{3}{*}{$\begin{array}{l}\text { Phytophthora } \\
\text { species }\end{array}$} & \multirow[t]{3}{*}{ Treatment } & \multirow{3}{*}{$\begin{array}{l}\text { Temperature } \\
\left({ }^{\circ} \mathrm{C}\right)\end{array}$} & \multicolumn{6}{|c|}{ Time after application to bark } \\
\hline & & & \multicolumn{2}{|c|}{$1 \mathrm{~d}$} & \multicolumn{2}{|c|}{3 wk } & \multicolumn{2}{|c|}{$5 \mathrm{wk}$} \\
\hline & & & Mean \% & $\mathrm{n}$ & Mean \% & $\mathrm{n}$ & Mean \% & $\mathrm{n}$ \\
\hline \multirow[t]{6}{*}{ P. kernoviae } & Fresh control $^{1}$ & - & 65 & 400 & 45 & 400 & 50 & 400 \\
\hline & Mesh A & 15 & 17 & 381 & 0 & 285 & 0 & 400 \\
\hline & & 20 & 36 & 400 & 0 & 400 & 0 & 400 \\
\hline & & 25 & 36 & 265 & 0 & 400 & 0 & 400 \\
\hline & & 30 & 38 & 400 & 0 & 400 & 0 & 400 \\
\hline & & 35 & 24 & 400 & 0 & 400 & 0 & 400 \\
\hline \multirow[t]{6}{*}{ P. pluvialis } & Fresh control $^{1}$ & - & 0 & 400 & 0 & 400 & 1 & 400 \\
\hline & Mesh F & 15 & 0 & 202 & 0 & 365 & 0 & 265 \\
\hline & & 20 & 0 & 47 & 0 & 400 & 0 & 213 \\
\hline & & 25 & 0 & 140 & 0 & 400 & 0 & 153 \\
\hline & & 30 & 0 & 227 & 0 & 321 & 0 & 124 \\
\hline & & 35 & 0 & 86 & 0 & 400 & 0 & 273 \\
\hline
\end{tabular}

${ }^{1}$ Control suspensions prepared fresh at each sampling time (2 replicates).

a bark washing of a segment from the $20^{\circ} \mathrm{C}$ chamber at sample time 4.5 weeks (Treatment A, not heated) in Study 1. In Study 2, colonies of Phytophthora kernoviae grew on this medium from nylon disc oospore suspensions made 1 day after treatment on bark at $15^{\circ} \mathrm{C}, 20^{\circ} \mathrm{C}, 25^{\circ} \mathrm{C}$, and $35^{\circ} \mathrm{C}$. However, no Phytophthora spp. cultures grew on this medium from oospore suspensions of Phytophthora kernoviae sampled from at least 3 weeks or more after treatment at all temperatures in Study 2. Similarly, none grew from oospore suspensions of Phytophthora pluvialis from 1 day or more after treatment at all temperatures in the same study.

\section{Colonisation of bark and sapwood}

No Phytophthora spp. were recovered from either the bark or sapwood core sections from segments inoculated with zoospores, mycelium or oospore suspensions.

\section{Discussion}

There is growing concern that with increased international trade the unintentional movement of forest pests and diseases between countries has become more likely (Evans 2010). Forest products such as timber and dunnage present less risk than that due to the interchange of living plants (Brasier 2008; Santini et al. 2013), but nevertheless remain a potential biosecurity threat. Importing countries may, therefore, view Pinus radiata logs as a possible risk for transport of Phytophthora pluvialis and Phytophthora kernoviae. The work reported in this paper was designed to investigate this question. Taken together, the results of the studies suggest that the movement of these species on pine logs appears unlikely. The needle and leaf bark baiting study found no evidence of naturally occurring viable contamination of tree stems by Phytophthora species. And, notwithstanding this, should any propagules still be present, the experiments using artificially applied inoculum demonstrated a substantial decline in the percentage remaining vital, suggesting that, at best, few would survive on pine logs during the course of a journey of several weeks.

Different aspects of the potential log transport risk were covered by the three approaches used in this work. The first procedure addressed the possibility that propagules of these Phytophthora species propagules might occur naturally on the bark surface. Two sampling methods were employed, both of which involved testing for released zoospores by means of foliage baiting. The baits used were identified in preliminary tests as the most consistent and sensitive from among a range of different tree and shrub species for recovering these Phytophthora species should they be present (NW, unpublished data). Baiting in this way for 5 days had resulted in the regular isolation of Phytophthora pluvialis at concentrations of and above 370 zoospores $\mathrm{mL}^{-1}$ and Phytophthora kernoviae at concentrations of and above 160 zoospores $\mathrm{mL}^{-1}$ (PS, unpublished data). The technique was, therefore, sufficiently sensitive to detect zoospores at concentrations lower than those that failed to colonise bark or wood when applied artificially in the other studies (cf. Ahumada et al. 2012).

The second approach tested the survival of propagules applied artificially to the bark on Pinus radiata segments. Three studies were required in order to compensate for the difficulties encountered in producing all propagules simultaneously. Among the possible 'hitchhiker' agents considered, zoospores and caducous sporangia are shortlived propagules, vulnerable to drying, that enable 
Phytophthora species to infect living tissues but are unlikely to play a part in their longer-term dispersal on logs. Sporangia and zoospores were examined for completeness but there was no evidence of their survival. Attention was, therefore, directed towards oospores which form the persistent resting stage of many Phytophthora species (Sneh and McIntosh 1974; Stack and Millar 1985; Erwin and Ribeiro 1996). Widmer (2011) found that Phytophthora kernoviae survived in soil only by producing oospores. It is difficult to conceive how oospores would find their way onto the surfaces of radiata pine logs unless they are present either in adhering pine needles or in soil containing fallen infected needles that have decomposed. However, naturally produced oospores of both Phytophthora kernoviae and especially Phytophthora pluvialis are not commonly observed in in radiata pine needles in New Zealand (MD, unpublished data). In a separate study, only one oospore was found during the sectioning and microscopic examination of 600 symptomatic Pinus radiata needles exposed at intervals in the field during September and October, 2012 (NW, unpublished data). It is possible that season may influence oospore production in nature, and further research into these aspects is underway.

In the artificially applied propagule studies, the trend of decreasing oospore viability or vitality with time for Phytophthora kernoviae, particularly at the higher temperatures, was consistent between all four evaluation methods. Oospore germination and mycelial growth of this species from suspensions placed onto the Phytophthoraspecific isolation medium were both almost non-existent beyond the first week when compared to those in the freshly prepared control suspensions. Likewise, frequency of isolation of Phytophthora kernoviae declined over time at all temperatures in Study 1, more so when these were higher, yields falling rapidly to zero at temperatures of $25^{\circ} \mathrm{C}$ and over. In agreement with this it was found that heating the oospore suspension to $35^{\circ} \mathrm{C}$ before applying it to the segments also reduced the isolation yield over the full period (Treatment D versus A). That this was due simply to the death of mycelial fragments prior to application seems doubtful since, like zoospores and sporangia, hyphae are vulnerable and regardless of treatment are unlikely to have survived for more than a short time on the nonsterile bark surface. Supporting this, isolates were not obtained from hyphal fragments associated with the unheated Phytophthora kernoviae sporangia and zoospore treatment in the same study (Treatment B). Oospore suspensions were heated before application to the bark only in Study 1. Since this treatment appeared to affect the viability of $P$. kernoviae, pre-heating of oospore suspensions was omitted for both species in Study 2 to avoid the possibility of obtaining an underestimate of survival incidence.
Propagules of Phytophthora pluvialis proved to be less responsive when compared with Phytophthora kernoviae in the same studies, showing no evidence of viability, whether by isolation or oospore germination, even in fresh control suspensions. This was also true with respect to growth after pipetting onto the Phytophthora-selective medium (if one disregards the cultures obtained from the fresh control suspensions prepared almost immediately on the same day and which therefore, in this situation, probably did grow from still living hyphal fragments). The lack of viability shown by oospores of Phytophthora pluvialis, in contrast to those of Phytophthora kernoviae, was consistent in both studies. For Study 1, it seems doubtful that this species distinction in oospore activity can be explained by the different periods of heating before application to the bark (Treatments C and D, respectively; Table 1). Isolation showed that oospores of Phytophthora kernoviae were still viable early in the study, despite $15 \mathrm{hr}$ of heating at $35^{\circ} \mathrm{C}$. On the other hand, Phytophthora pluvialis was not reisolated even though oospores were heated for only $2 \mathrm{hr}$ at $35^{\circ} \mathrm{C}$ prior to application. Study 1 was incomplete in that it lacked both non-heated oospore and sporangia/zoospore treatments for Phytophthora pluvialis because, for this species, these propagules were not always produced consistently when required. Hence the undertaking of Study 2 and Study 3, to ensure that all spore treatment types were ultimately tested.

Nevertheless, despite their lack of viability, tetrazolium bromide staining demonstrated not only that oospores of Phytophthora pluvialis were alive in the freshly prepared suspensions in both Study 1 and Study 2, but that their vitality also decreased with time in a similar manner to that of Phytophthora kernoviae in the same studies. It is noteworthy that with both species oospore vitality as measured by tetrazolium bromide staining was greater than that indicated by oospore germination, a result that mirrored those of Widmer (2011), who speculated that for Phytophthora kernoviae, oospores become dormant at $30^{\circ} \mathrm{C}$, but may remain viable and be possibly able to germinate when dormancy is broken. For Phytophthora pluvialis, the resting oospores may require some kind of stimulus such as exposure to a host exudate or specific nutrient or an abrupt change in temperature or lighting before germination can occur (Zentmyer and Erwin 1970; Erwin and Ribeiro 1996).

It has been suggested that the oospores used in laboratory studies may not be as hardy as those produced naturally, by analogy with the behaviour of Phytophthora ramorum Werres, De Cock \& Man in 't Veld, which produces thicker-walled oospores in nature than in culture (C. M. Brasier, T. Jung, personal communication). Widmer (2010) used both germination and ability to stain in tetrazolium bromide as the criteria for Phytophthora kernoviae oospore maturity. He found that the latter 
plateaued after ca. 2 weeks in liquid culture while maximum germination occurred after $8-10$ weeks. We also found that the frequency of vital staining of oospores of this species was high in suspensions prepared after 2 weeks in clarified V8 broth, and that oospores readily germinated in freshly prepared control suspensions. Oospores of Phytophthora pluvialis came from plates over 1 month old, were thick walled $(\sim 3-5 \mu \mathrm{m})$ and also showed a high frequency of vital staining when first extracted.

Oospore numbers of both species were often low and irregular during germination counts in Study 1 because of the unavoidable confounding effects of minute obstructing bark fragments and the limited volumes available in the microscope cavity slides. For this reason, nylon-mesh discs were used in Study 2, which confirmed the validity of these oospore germination results when using a greater number of propagules, even if contact with the bark was less intimate.

The third approach in this project examined another potential means of log contamination, namely the possibility of colonisation of the inner bark (phloem) or outer xylem before or after felling. This aspect was reviewed by Ahumada et al. (2012), who investigated the risk of spreading Phytophthora pinifolia from Chile in sawn green Pinus radiata timber. A number of foliage-infecting Phytophthora species, including Phytophthora pseudosyringae T. Jung \& Delatour (phylogenetically closely related to Phytophthora pluvialis) and Phytophthora kernoviae, are known to produce stem cankers on some hardwood hosts but apart from Phytophthora ramorum, Phytophthora pinifolia and Phytophthora lateralis Tucker \& Milbrath there are no reports of these species from conifers (Green et al. 2013; Robin et al. 2011; Webber et al. 2012; Scanu et al. 2012; Brasier et al. 2005; Brown and Brasier 2007; Parke et al. 2007; Durán et al. 2008; Wickland et al. 2008; Collins et al. 2009; EPPO 2013). If such colonisation were to occur, it could also lead to the production of oospores within the bark. In New Zealand Phytophthora-associated cankers or resin bleeding have not been recorded in Pinus radiata. Isolations from symptomatic needles and associated shoots have indicated that infection is limited to needle tissues with no occurrence of twig or branch colonisation (Dick et al. 2014). Although successful inoculations have been conducted using detached needles and needles on potted plants (Dick et al. 2014), attempts to inoculate bark and sapwood in the work reported here were unsuccessful. This was true despite the fact that treatments were applied under different conditions (high or ambient humidity) using a variety of propagules (mycelium, zoospores, oospores). If these species were able to colonise the bark or sapwood, at least one of these sets of circumstances should have revealed this. For instance, the ability to isolate Phytophthora kernoviae periodically after spraying oospores across the bark surface during Study 1 suggests that had colonisation taken place it should have been possible to recover this species adjacent to a single bark or sapwood inoculation point. Ahumada et al. (2012) were also unable to demonstrate the survival of Phytophthora pinifolia in wood of Pinus radiata after artificial inoculation $\left(50,000\right.$ zoospores $\left.\mathrm{mL}^{-1}\right)$ or exposure to natural inoculum in diseased plantations, even though this species is able to move from infected needles into the succulent cambial tissue in young branches (Ahumada et al. 2012, 2013). The outcomes from our studies with Phytophthora pluvialis and Phytophthora kernoviae imply that the conclusions of Ahumada et al. (2012) are also applicable to green radiata pine timber exported from New Zealand.

\section{Conclusion}

The risk of moving Phytophthora pluvialis and Phytophthora kernoviae from New Zealand forests to a new location on logs harvested from stands where they are present can be broken down into three components: the likelihood of their presence in viable form on the logs; if present, the chances of their survival during transport; and, if surviving, their prospects for establishing at the new location. Of these, the first, presence on logs, was addressed using two approaches presented in this paper. This work showed that, although commonly isolated from freshly infected needles, there was no evidence that these species either colonise or superficially contaminate radiata pine logs from external inoculum landing on the surface. There is still a possibility that oospores might be present in needles or soil accompanying log shipments, but in accordance with international standards, export forest produce is kept free of such material. Preliminary examination found little indication of oospores in symptomatic, infected needles, but there is a need for more complete information.

The second potential risk component, survival during transport, was addressed in three studies that examined the persistence of propagules applied artificially to the bark surface. Results of this work suggested that should small numbers of oospores be present on logs in transit, the overall likelihood that significant numbers will survive a journey is limited.

The third component of risk considers the likelihood of these Phytophthora species establishing and spreading should viable propagules survive log transport to a new location. This component is complex and was not dealt with in the present investigation. Establishment is less likely to succeed when only a scattering of surviving individuals or propagules, rather than a 'population' of an invading organism, reach a new destination (Van der Plank 1975; Lindemann et al. 1984; Garrett and Bowden 2002). As noted, the results of the work reported here 
imply that at most the number of propagules surviving transport in a form in which they might be able to germinate or sporulate would be limited, suggesting further that the 'threat' from these organisms being associated with the import of logs is likely to be minimal.

From their studies, Ahumada et al. (2012) determined that the shipping of sawn timber does not appear to be a likely path for the transport of Phytophthora pinifolia from Chile. Although some questions remain to be answered, our work investigating the risk of transporting Phytophthora pluvialis and Phytophthora kernoviae on radiata pine logs from New Zealand points to a similar conclusion.

\section{Competing interests}

The authors declare that although partly funded by the New Zealand Forest Owners' Association this has in no way affected the scientific integrity of the work presented in this paper.

\section{Authors' contributions}

IH undertook Studies 1 and 2 in the second section, survival of artificially applied propagules, with the substantial collaboration and support of MD, NA and JG. NW conducted Study 3 and also the work in the first and third sections, natural occurrence and colonisation of bark and sapwood, while PS determined the sensitivity of the baiting technique. MK carried out the statistical analyses. The paper was written by $\mathrm{HH}$ and NW, assisted by MD and MK, and all authors read and approved the final manuscript.

\section{Acknowledgements}

The following are thanked for their technical or specialist assistance: Martin Bader, Catherine Banham, Debra Bly, Kane Fleet, Heather Flint, Marcel van Leeuwen, Rebecca McDougal, Mark Miller, Nalini Navaranjan, Toby Stovold, Pam Taylor, Rita Tetenburg, Tia Uaea, Mitchell West and Liam Wright. We are also grateful for discussion and advice to: Anna Brown, Lindsay Bulman, Bill Dyck, Ruth Falshaw, Peter Gadgil, Beccy Ganley, George Gill, Don Hammond, Wellcome Ho, Dave Lowry, Terry (Charles) Shaw, Paul Stevens, Ivan Velijkovic, and Wei-Young Wang. Helpful criticism was provided by four anonymous reviewers. Funding was provided by the New Zealand Forest Owners' Association and the New Zealand Ministry of Business, Innovation and Employment.

NA thanks the Swedish Foundation for International Cooperation in Research and Higher Education (STINT)-funded exchange programme between Scion and the Swedish University of Agricultural Sciences.

\section{Author details}

${ }^{1}$ Scion (New Zealand Forest Research Institute), Private Bag 3020, Rotorua 3046, New Zealand. ${ }^{2}$ Department of Forest Mycology and Pathology, Swedish University of Agricultural Sciences, Box 7026, 75007 Uppsala, Sweden.

Received: 15 January 2013 Accepted: 5 February 2014

Published online: 23 May 2014

\section{References}

Ahumada, R, Rotella, A, Slippers, B, \& Wingfield, MJ. (2012). Potential of Phytopthora pinifolia to spread via sawn green lumber: a preliminary investigation. Southern Forests, 74, 211-216.

Ahumada, R, Rotella, A, Slippers, B, \& Wingfield, MJ. (2013). Pathogenicity and sporulation of Phytopthora pinifolia on Pinus radiata in Chile. Australasian Plant Pathology, 42, 413-420.

Beales, PA, Giltrap, PG, Payne, A, \& Ingram, N. (2009). A new threat to UK heathland from Phytophthora kernoviae on Vaccinium myrtillus in the wild. Plant Pathology, 58, 393.

Brasier, CM. (2008). The biosecurity threat to the UK and global environment from international trade in plants. Plant Pathology, 57, 792-808.

Brasier, CM, Beales, PA, Kirk, SA, Denman, S, \& Rose, J. (2005). Phytophthora kernoviae sp. nov., an invasive pathogen causing bleeding stem lesions on forest trees and foliar necrosis of ornamentals in the UK. Mycological Research, 109, 853-859.

Brown, AV, \& Brasier, CM. (2007). Colonization of tree xylem by Phytophthora ramorum, P. kernoviae and other Phytophthora species. Plant Pathology, 56, 227-241.

Collins, BR, Parke, JL, Lachenbruch, B, \& Hansen, EM. (2009). The effects of Phytophthora ramorum infection on hydraulic conductivity and tylosis formation in tanoak sapwood. Canadian Journal of Forest Research, 39 1766-1776.

Crosby, TK, Dugdale, JS, \& Watt, JC. (1988). Area Codes for recording specimen localities in the New Zealand sub-region. New Zealand Journal of Zoology, 25, 175-183.

Dick, MA, Williams, NM, Bader, MK-F, Gardner, JF, \& Bulman, LS (2014). Pathogenicity of Phytophthora pluvialis to Pinus radiata and its relation with red needle cast disease in New Zealand. New Zealand Journal of Forestry Science, 44, 6.

Durán, A, Gryzenhout, M, Slippers, B, Ahumada, R, Rotella, A, Flores, F, Wingfield, BD, \& Wingfield, MJ. (2008). Phytophthora pinifolia sp. nov. associated with a serious needle disease of Pinus radiata in Chile. Plant Pathology, 57, 715-727.

EPPO. (2013). PM 7/112 (1) Phytophthora kernoviae. EPPO Bulletin, 43, 81-93. Paris: European and Mediterranean Plant Protection Organization.

Erwin, DC, \& Ribeiro, OK. (1996). Phytophthora diseases worldwide. St. Paul, MI, USA: The American Phytopathological Society.

Etxeberria, A, Mendarte, S, \& Larregla, S. (2011). Determination of viability of Phytophthora capsici oospores with the tetrazolium bromide staining test versus a plasmolysis method. Revista Iberoamericana de Micología, 28, 43-49.

Evans, HF. (2010). Pest risk analysis - organisms or pathways? New Zealand Journal of Forestry Science, 40 supplement, S35-S44.

Garrett, KA, \& Bowden, RL. (2002). An Allee effect reduces the invasive potential of Tilletia indica. Phytopathology, 92, 1152-1159.

Green, S, Brasier, CM, Schlenzig, A, McCracken, A, MacAskill, GA, Wilson, M, \& Webber, JF. (2013). The destructive invasive pathogen Phytophthora lateralis found on Chamaecyparis lawsoniana across the UK. Forest Pathology, 43, 19-28. [doi: 10.1111/j.1439-0329.2012.00788.x]

Jeffers, SN, \& Martin, SB. (1986). Comparison of two media selective for Phytophthora and Pythium species. Plant Disease, 70, 1038-1043.

Lindemann, J, Arny, DC, \& Upper, CD. (1984). Use of an apparent infection threshold population of Pseudomonas syringae to predict incidence and severity of brown spot of bean. Phytopathology, 74, 1334-1339.

Parke, JL, Oh, E, Voelker, S, Hansen, EM, Buckles, G, \& Lachenbruch, B. (2007). Phytophthora ramorum colonizes tanoak xylem and is associated with reduced stem water transport. Phytopathology, 97, 1558-1567.

Ramsfield, TD, Dick, MA, Beever, RE, Horner, IJ, McAlonan, MJ, \& Hill, CF. (2009). Phytophthora kernoviae in New Zealand. In EM Goheen \& SJ Frankel (Eds.), Phytophthoras in Forests and Natural Ecosystems. Proceedings of the Fourth Meeting of the International Union of Forest Research Organizations (IUFRO) Working Party 507.02.09, August 26-31, 2007 (pp. 47-53). Monterey, California: General Technical Report PSW-GTR-221. Pacific Southwest Research Station, Albany, CA, USA: United States Department of Agriculture Forest Service.

Reeser, PW, Sutton, WL, \& Hansen, EM. (2013). Phytophthora pluvialis, a new species from mixed tanoak - Douglas-fir forests of western Oregon, U.S.A. North American Fungi, 8(7), 1-8.

Robin, C, Piou, D, Feau, N, Douzon, G, Schenck, N, \& Hansen, EM. (2011). Root and aerial infections of Chamaecyparis lawsoniana by Phytophthora lateralis: a new threat for European countries. Forest Pathology, 41, 417-424. [doi: 10.1111/j.1439-0329.2010.00688.x]

Santini, A, Ghelardini, L, De Pace, C, Desprez-Loustau, ML, et al. (2013). Biogeographical patterns and determinants of invasion by forest pathogens in Europe. New Phytologist, 197, 238-250.

Scanu, B, Jones, B, \& Webber, JF. (2012). A new disease of Nothofagus in Britain caused by Phytophthora pseudosyringae. New Disease Reports, 25, 27. [doi: 10.5197/j.2044-0588.2012.025.027]

Sneh, B, \& McIntosh, DL. (1974). Studies on the behaviour and survival of Phytophthora cactorum in soil. Canadian Journal of Botany, 52, 795-802.

Stack, JP, \& Millar, RL. (1985). Relative survival potential of propagules of Phytophthora megasperma f.sp. medicaginis. Phytopathology, 75, 1398-1404.

Sutherland, ED, \& Cohen, SD. (1983). Evaluation of tetrazolium bromide as a vital stain for fungal oospores. Plant Disease, 73, 1532-1535.

Theron, JM, Donald, DGM, Broembsen, SL, \& van der Merwe, JA. (1982). The effect of warm water treatment of Pinus radiata seedlings on mycorrhizae survival, root growth capacity and Phytophthora eradication. South African Forestry Journal, 123, 31-35. 
Van der Plank, JE. (1975). Principles of plant infection. New York, NY, USA: Academic Press, Inc

Webber, JF, Vettraino, AM, Chang, TT, Bellgard, SE, Brasier, CM, Vannini, A. (2012). Isolation of Phytophthora lateralis from Chamaecyparis foliage in Taiwan. Forest Pathology, 42, 136-143. [doi: 10.1111/j.1439-0329.2011.00729.x]

Wickland, AC, Jensen, CE, \& Rizzo, DM. (2008). Geographic distribution, disease symptoms and pathogenicity of $P$. nemorosa and $P$. pseudosyringae in California, USA. Forest Pathology, 38, 288-298.

Widmer, TL. (2010). Phytophthora kernoviae oospore maturity, germination, and infection. Fungal Biology, 114, 661-668.

Widmer, TL. (2011). Effect of temperature on survival of Phytophthora kernoviae oospores, sporangia and mycelium. New Zealand Journal of Forestry Science, 41 Supplement, S15-S23.

Zentmyer, GA, \& Erwin, DC. (1970). Development and reproduction of Phytophthora. Phytopathology, 60, 1120-1143.

Zentmyer, GA, \& Ribeiro, OK. (1977). The effect of visible and near-visible radiation on sporangium production by Phytophthora cinnamomi. Phytopathology, 67, 91-95.

doi:10.1186/s40490-014-0007-6

Cite this article as: Hood et al:: Decline in vitality of propagules of

Phytophthora pluvialis and Phytophthora kernoviae and their inability to contaminate or colonise bark and sapwood in Pinus radiata export log simulation studies. New Zealand Journal of Forestry Science 2014 44:7.

\section{Submit your manuscript to a SpringerOpen ${ }^{\circ}$ journal and benefit from:}

- Convenient online submission

- Rigorous peer review

- Immediate publication on acceptance

- Open access: articles freely available online

- High visibility within the field

- Retaining the copyright to your article 